\title{
Regulation of estrogen receptor- $\alpha$ gene expression by epidermal growth factor
}

\author{
A Stoica, M Saceda, V L Doraiswamy, C Coleman and \\ M B Martin
}

Lombardi Cancer Center, Department of Biochemistry and Molecular Biology, Georgetown University, 3970 Reservoir Rd NW, Washington DC 20007-2197, USA

(Requests for offprints should be addressed to M B Martin, Lombardi Cancer Center, E411 Research Building, 3970 Reservoir Rd NW, Washington DC 20007, USA)

(A Stoica and M Saceda contributed equally to this paper)

(M Saceda is now at the Department of Pharmacology, Universidad Miguel Hernandez, Campus de San Juan, Alicante, Spain)

\begin{abstract}
The role of epidermal growth factor (EGF) in the regulation of estrogen receptor- $\alpha(E R-\alpha)$ gene expression in the human breast cancer cell line MCF-7 was investigated. Treatment of cells with $0.4 \mathrm{ng} / \mathrm{ml}$ EGF resulted in an approximately $60 \%$ decrease in ER- $\alpha$ protein concentration by $6 \mathrm{~h}$ and the amount of receptor remained suppressed for $24 \mathrm{~h}$. Ligand binding assays demonstrated that the decrease in ER- $\alpha$ protein corresponded to a similar decrease (approximately 50\%) in estradiol binding sites. Although EGF treatment resulted in a decrease in the number of binding sites, it had no effect on the binding affinity of ER- $\alpha$. The dissociation constant of the estradiol-ER- $\alpha$ complex in the presence or absence of EGF was the same $\left(K_{\mathrm{d}}=2 \cdot 3 \times 10^{-10} \mathrm{M}\right.$ in control cells versus $K_{\mathrm{d}}=1.98 \times 10^{-10} \mathrm{M}$ in EGF-treated cells). The decrease in ER- $\alpha$ protein concentration paralleled a decrease in the steady-state amount of ER- $\alpha$ mRNA. By $9 \mathrm{~h}$ there was an approximately $60 \%$ decrease in ER- $\alpha$ mRNA. The amount of ER- $\alpha$ mRNA remained suppressed for $48 \mathrm{~h}$. Transcription run-on experiments demonstrated that there was a decrease of approximately $70 \%$
\end{abstract}

in ER- $\alpha$ gene transcription upon EGF treatment, suggesting that the mechanism by which EGF regulates ER- $\alpha$ gene expression is transcriptional. In addition to regulating the amount of ER- $\alpha$, EGF affected the activity of the receptor. At high concentrations, EGF induced progesterone receptor. Estradiol and high concentrations of EGF had an additive effect on progesterone receptor. In contrast to high concentrations, low concentrations of EGF had no effect on progesterone receptor and blocked estradiol induction. The effects of EGF on ER- $\alpha$ expression were inhibited by tyrphostins and wortmannin, suggesting that the effects of the growth factor are mediated by the EGF receptor and protein kinase $\mathrm{B}$. When the cells were placed in serum-free medium and then treated with EGF, there was no effect on ER- $\alpha$ protein concentration or activity. However, increasing concentrations of serum restored the effects of EGF on ER- $\alpha$, suggesting that an additional serum factor was required for the EGF-mediated effect on the decrease in ER- $\alpha$ protein concentration.

Journal of Endocrinology (2000) 165, 371-378

\section{Introduction}

Recent world estimates reveal that the most prevalent cancer in women is breast cancer. It is the leading cause of death in women between the ages of 35 and 45 . Estrogens influence the proliferation, differentiation and physiology of normal breast tissue as well as the development and progression of breast cancer (Picard et al. 1997). Most of the actions of estrogen are mediated by the estrogen receptor (ER) (Katzenellenbogen 1996), a member of a large superfamily of structurally and functionally related nuclear transcription factors (Mangelsdorf et al. 1995, Katzenellenbogen et al. 1997).
It has long been recognized that many human breast cancers are initially hormone-dependent which has led to the utilization of antiestrogens in the treatment of breast cancer (Jensen 1996). The presence of ER is employed in the selection of patients for hormone therapy. It is also an important prognostic marker that correlates with higher survival rates and a lower risk of relapse. Although initially hormone-dependent, most tumors progress to a hormoneindependent phenotype. The progression of breast cancer from estrogen-stimulated and antiestrogen-sensitive growth to estrogen-independent and antiestrogen-resistant proliferation is well documented (Picard et al. 1997) but remains poorly understood and may involve the action of 
several growth factors. Cross-talk between the estrogen and growth factor pathways occurs when the growth factor initiates a phosphorylation cascade which may activate the ER independent of the presence of estrogens (Norderu et al. 1994, Adachi et al. 1995).

Epidermal growth factor (EGF) is a $6 \mathrm{kDa}$ heat- and acid-stable peptide which stimulates proliferation of many normal or malignant cells (Cho et al. 1994). The biological effects of EGF are triggered by binding to the EGF receptor, a member of a growth factor receptor family which also includes the proteins erbB2, erbB3 and erbB4 (HER2, HER3 and HER 4 respectively) (Earp et al. 1995). In advanced breast cancer, overexpression of the EGF receptor and erbB2 correlates with poor prognosis (Earp et al. 1995). There is an inverse correlation between the EGF receptor and ER concentrations. Estrogen receptor positive/EGF receptor negative tumors have a better prognosis than ER negative/EGF receptor positive tumors. Epidermal growth factor receptor positive tumors are hormone unresponsive and more aggressive than EGF receptor negative tumors.

Epidermal growth factor was shown to elicit ERdependent physiologic sequelae and to demonstrate estrogen-like biochemical effects in the mouse uterus (Stancel et al. 1987, Hana \& Murphy 1994, IgnarTrowbridge et al. 1995). In addition, the uterine response to both steroid hormones and growth factors is absent in the ER- $\alpha$ wild-type knock-out transgenic mouse (Curtis et al. 1996). Epidermal growth factor also induces transcriptional activation of a consensus estrogen response element in an ER-dependent manner in Ishikawa human endometrial adenocarcinoma cells, in BG-1 human adenocarcinoma cells, as well as in HeLa cells co-transfected with ER and an estrogen response element-luciferase reporter gene (Ignar-Trowbridge et al. 1993, Bunone et al. 1996). In MCF-7 cells, EGF induces an increase in the LIV$1 \mathrm{mRNA}$ and pS2 mRNA in the absence of estradiol and the induction was abolished by the antiestrogen ICI 164, 384 (El-Tanani \& Green 1997a). However, in MCF-7 cells transiently transfected with an estrogen response element-luciferase reporter construct, EGF had no stimulatory effect on luciferase expression (Hafner et al. 1996). The precise biochemical mechanisms by which the actions of estrogens and EGF converge are unknown (O'Malley et al. 1994) and may very well be cell type and promoter specific (Ignar-Trowbridge et al. 1996). The goal of this investigation was to elucidate the role of EGF in the ER- $\alpha$ gene expression in the breast cancer cell line MCF-7. The effects of EGF on the steady-state concentration of ER- $\alpha$ protein, mRNA and gene transcription were measured. The effects of EGF on ER- $\alpha$ activity were also studied.

\section{Materials and Methods}

Tissue culture

Monolayer cultures of MCF-7 breast cancer cells were grown in Improved Minimal Essential Medium (IMEM) supplemented with $5 \%(\mathrm{vol} / \mathrm{vol})$ fetal calf serum. When the cells were $70 \%$ confluent, the medium was replaced with phenol red-free IMEM containing 5\% charcoaltreated calf serum. Calf serum was pretreated with sulfatase and dextran-coated charcoal to remove endogenous steroids. After 2 days in these conditions, the cells were treated with $1 \mathrm{nM}$ estradiol (Sigma, St Louis, MO, USA) or $0.4 \mathrm{ng} / \mathrm{ml}$ EGF (Upstate Biotechnology, Lake Placid, NY, USA) for the appropriate times. For experiments which utilized serum free medium (IMEM supplemented with $2 \mathrm{mg} / \mathrm{ml}$ fibronectin, $5 \mathrm{ng} / \mathrm{ml}$ HEPES, glutamine, transferrin and trace elements), cells were placed in phenol red-free IMEM containing 5\% charcoal-treated calf serum for 2 days. The cells were then placed in serum free medium at the initiation of the treatments.

\section{Plasmids}

The probe for the ER- $\alpha$, pOR-300, was constructed by subcloning a $300 \mathrm{bp}$ restriction fragment of pOR 3 into the pGem4 polylinker regions using the restriction enzymes PstI and EcoRI (Saceda et al. 1988). The genomic clone corresponding to exon $1, \mathrm{Q} 7$, is a $3 \mathrm{~kb}$ EcoRI-SalI fragment subcloned into Bluescript M13+ (Stratagene, La Jolla, CA, USA) (Saceda et al. 1988). The clone 36B4 was constructed by subcloning a $220 \mathrm{bp}$ fragment of 36B4 into the PstI restriction site of the pGem polylinker (Saceda et al. 1988). In addition, the clones for glyceraldehyde-3phosphate dehydrogenase (GAPDH) (Kastner et al. 1990) and progesterone receptor (Ignar-Trowbridge et al. 1992) were constructed as previously described.

\section{ER- $\alpha$ and progesterone receptor protein assays}

For analysis of ER- $\alpha$ and progesterone receptor protein concentration, MCF-7 cells were cultured and treated as described above. The concentration of receptor protein was determined using an enzyme immunoassay kit from Abbott Laboratories (North Chicago, IL, USA). To obtain total receptor protein, the cells were homogenized by sonication in a high salt buffer $(10 \mathrm{mM}$ Tris, $1.5 \mathrm{mM}$ EDTA, $5 \mathrm{mM} \mathrm{Na}_{2} \mathrm{MoO}_{4}, 0 \cdot 4 \mathrm{M} \mathrm{KCl}$, and $1 \mathrm{mM}$ monothioglycerol with $2 \mathrm{mM}$ leupeptin). The homogenate was incubated on ice for $30 \mathrm{~min}$ and centrifuged at $100000 \mathrm{~g}$ for $1 \mathrm{~h}$ at $4{ }^{\circ} \mathrm{C}$. Aliquots of the total extracts were then analyzed according to the manufacturer's instructions.

To measure the number of estrogen binding sites and the dissociation constant $\left(K_{\mathrm{d}}\right)$ of the estradiol-ER- $\alpha$ complex, a whole cell, multiple-dose ligand binding assay was used (Stoica et al. 1997). Cells were plated in six-well plates. At approximately $70 \%$ confluence, the cells were treated with $0 \cdot 4 \mathrm{ng} / \mathrm{ml} \mathrm{EGF}$ for $24 \mathrm{~h}$. The cells were then incubated for $1 \mathrm{~h}$ with various concentrations of $\left[{ }^{3} \mathrm{H}\right]$ estradiol. A 200-fold excess of diethylstilbestrol was added to distinguish between specific and nonspecific binding. The cells were washed and lysed. The protein content and 
radioactivity present in each sample was quantified and analyzed using the Scatchard method.

\section{Measurement of ER-a mRNA}

Total cellular RNA was extracted from MCF-7 cells by the RNazol method. The amounts of ER- $\alpha, 36 \mathrm{~B} 4$, progesterone receptor and GAPDH were determined by an RNase protection assay. Briefly, homogeneously ${ }^{32} \mathrm{P}-$ labeled antisense cRNA were synthesized in vitro from pOR-300, 36B4, pGAPDH using T7 polymerase and from progesterone receptor using SP6. Sixty micrograms of total RNA were hybridized for $12-16 \mathrm{~h}$ to the radiolabeled cRNA. After a $30 \mathrm{~min}$ digestion at $25^{\circ} \mathrm{C}$ with RNase A, ${ }^{32} \mathrm{P}-$ labeled cRNA probes protected by total RNA were separated by electrophoresis on $6 \%$ polyacrylamide gels. The bands were visualized by autoradiography and quantified using the phosphor imager. The amounts of ER- $\alpha$ mRNA and progesterone receptor mRNA were normalized to the internal control 36B4 and GAPDH, respectively.

\section{Isolation of nuclei}

After treatment with EGF, MCF-7 cells were harvested and resuspended in $5 \mathrm{ml}$ phosphate buffer saline and pelleted by gentle centrifugation at $4{ }^{\circ} \mathrm{C}$ as previously described (Saceda et al. 1988). The pellet was resuspended in a buffer containing $10 \mathrm{mM}$ Tris $\mathrm{pH} 7 \cdot 5,10 \mathrm{mM} \mathrm{NaCl}$, $3 \mathrm{mM} \mathrm{MgCl}_{2}$ and $0 \cdot 5 \% \mathrm{NP}-40$. After $5 \mathrm{~min}$ on ice, the cells were centrifuged at $500 \mathrm{~g}$ at $4{ }^{\circ} \mathrm{C}$ for $5 \mathrm{~min}$. The precipitate was again resuspended in $4 \mathrm{ml}$ of the same buffer and centrifuged as described above. The nuclei from the second centrifugation were resuspended in $500 \mu \mathrm{l}$ of nuclei storage buffer $(20 \mathrm{mM}$ Hepes, $75 \mathrm{mM} \mathrm{NaCl}$, 0.5 mM EDTA, 0.85 mM DTT, 0.125 mM phenylmethylsulfonylfluoride, $50 \%$ glycerol). Nuclei were stored at $-70{ }^{\circ} \mathrm{C}$ until the transcription elongation assay was performed.

\section{Transcription run-on assay}

The isolated nuclei were in vitro transcribed by incubation in the presence of ATP, CTP, GTP and $\left[{ }^{32} \mathrm{P}\right]$ UTP for $1 \mathrm{~h}$ at $25^{\circ} \mathrm{C}$ as previously described (Saceda et al. 1988). The newly transcribed RNA was isolated by digestion with deoxyribonuclease and proteinase K. The RNA was then purified using RNazol followed by chloroform extraction and ethanol precipitation. Isolated RNA was hybridized to nitrocellulose blots containing cDNAs for ER- $\alpha$ (Q7), 36B4, pBR322, pS2, progesterone receptor, EGF receptor, actin and GAPDH. The samples were hybridized for 4 days at $42{ }^{\circ} \mathrm{C}$. After hybridization, the nitrocellulose blots were washed and exposed to X-ray film. Autoradiographs were analyzed by densitometry. Results were normalized by comparison with the transcriptional level of 36B4.

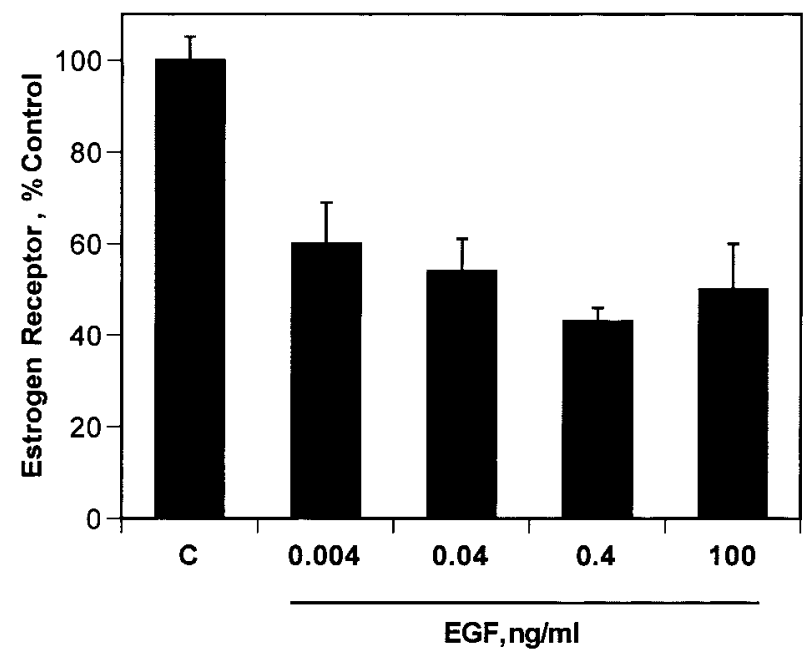

Figure 1 Effect of EGF on the ER- $\alpha$ protein concentration. MCF-7 cells were grown in IMEM supplemented with $5 \%$ fetal calf serum. At $80 \%$ confluence, the medium was changed to phenol red-free IMEM containing 5\% charcoal-stripped serum. Two days later, the cells were treated with various concentrations of EGF $(0 \cdot 004-100 \mathrm{ng} / \mathrm{ml})$ for $24 \mathrm{~h}$. Total ER- $\alpha$ was determined with an enzyme immunoassay as described in Materials and Methods. Results are presented as percentages of control values. Each point represents the mean value of four experiments \pm S.D.

\section{Results}

\section{Effect of EGF on the concentration of ER-a protein}

To determine whether EGF affects the expression of ER- $\alpha$, concentrations of $0 \cdot 004-100 \mathrm{ng} / \mathrm{ml}$ were tested for their ability to regulate ER- $\alpha$ protein concentration in the ER- $\alpha$ positive MCF-7 breast cancer cells. Cells were treated with EGF for $24 \mathrm{~h}$ and the concentration of ER protein was measured using an enzyme immunoassay. A decrease of 40-60\% was observed with increasing concentrations of EGF from 0.04 to $100 \mathrm{ng} / \mathrm{ml}$ (Fig. 1). To determine changes in ER- $\alpha$ protein concentration following EGF treatment, a time course was then performed using an EGF concentration of $0.4 \mathrm{ng} / \mathrm{ml}$ (Fig. 2). A maximal decrease of approximately $60 \%$ in the protein concentration of ER- $\alpha$ was observed at $6 \mathrm{~h}$ which was maintained for $24 \mathrm{~h}$.

To confirm that the decreased concentration of ER- $\alpha$ protein, as measured by the enzyme immunoassay, corresponded to a decreased number of estrogen-binding sites, a multiple-dose ligand binding assay was performed (Fig. 3). There was no change in the affinity of estradiol binding to the ER- $\alpha$ following EGF $(0 \cdot 4 \mathrm{ng} / \mathrm{ml})$ treatment. The dissociation constant of the $\left[{ }^{3} \mathrm{H}\right]$ estradiol-ER- $\alpha$ complex obtained in the presence or absence of EGF treatment was the same $\left(K_{\mathrm{d}}=2 \cdot 3 \pm 0 \cdot 2 \times 10^{-10} \mathrm{M}, n=3\right.$ in control cells compared with $K_{\mathrm{d}}=1.98 \pm 0.4 \times 10^{-10} \mathrm{M}, n=3$ in EGFtreated cells). However, an approximately $50 \%$ decrease in the number of estrogen binding sites from $232 \mathrm{fmol} / \mathrm{mg}$ 


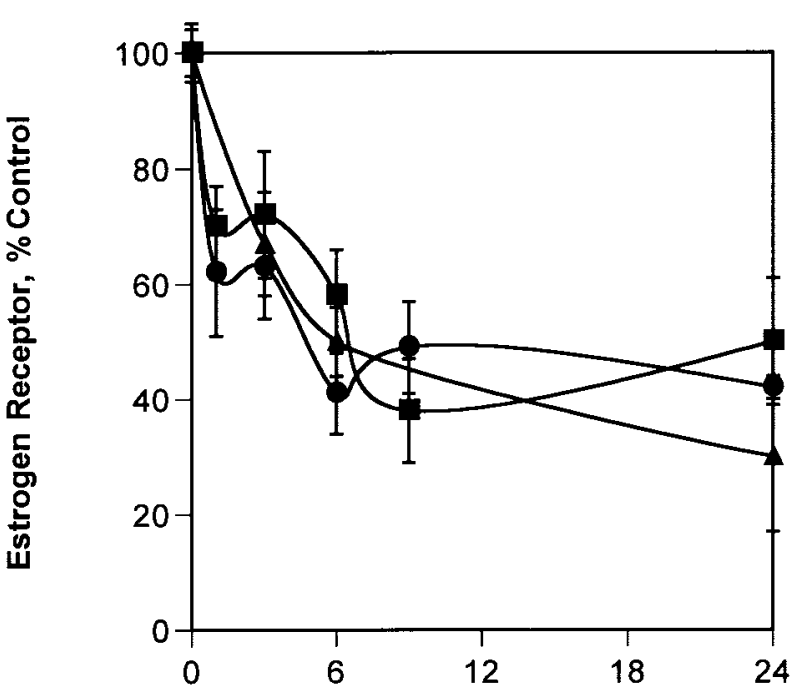

Time, hours

Figure 2 Time course of EGF regulation of ER- $\alpha$ protein, mRNA and gene transcription. MCF-7 cells were grown as described in Fig. 1 and treated with $0.4 \mathrm{ng} / \mathrm{ml}$ EGF for the times indicated. The concentration of ER- $\alpha$ protein was determined by an enzyme immunoassay as described in Materials and Methods. Total RNA was isolated using RNazol and $60 \mu \mathrm{g}$ of total RNA were analyzed using an RNase protection assay as described in Materials and Methods. Nuclei were isolated at the indicated times and the nuclear transcription run-on assay was performed as described in Materials and Methods. Results are presented as percentages of control values \pm S.D. $\mathbf{\square}$, ER- $\alpha$ protein $(n=8) ; 0$, ER- $\alpha$ mRNA $(n=6)$; $\boldsymbol{\Delta}$, ER- $\alpha$ gene transcription $(n=3)$.

protein in control cells to $116 \mathrm{fmol} / \mathrm{mg}$ protein in EGFtreated cells was observed. The decrease observed in the ligand binding assay correlates well with the $60 \%$ decrease in the concentration of ER- $\alpha$ protein measured by the enzyme immunoassay. These results indicate that the EGF-induced decrease in estradiol binding sites resulted from a change in ER- $\alpha$ protein concentration and was not due to a change in the binding affinity of the receptor.

\section{Effect of EGF on the steady-state amount of ER-a mRNA}

To determine whether the reduction in ER- $\alpha$ protein paralleled a reduction in the steady state amount of ER- $\alpha$ mRNA, an RNase protection assay was employed. MCF-7 cells were treated with $0.4 \mathrm{ng} / \mathrm{ml} \mathrm{EGF}$, and the effect of treatment on the steady state amount of total ER- $\alpha$ mRNA was measured. The change in ER- $\alpha$ mRNA was quantified by scanning densitometry and was normalized to the amount of 36B4 mRNA (Masiakowski et al. 1982). 36B4 is a ribosomal protein which is constitutively expressed in the presence of EGF. The results are presented in Fig. 2 as the ratio of the integrated ER- $\alpha$ signal to the integrated 36B4 signal. A maximal decrease of

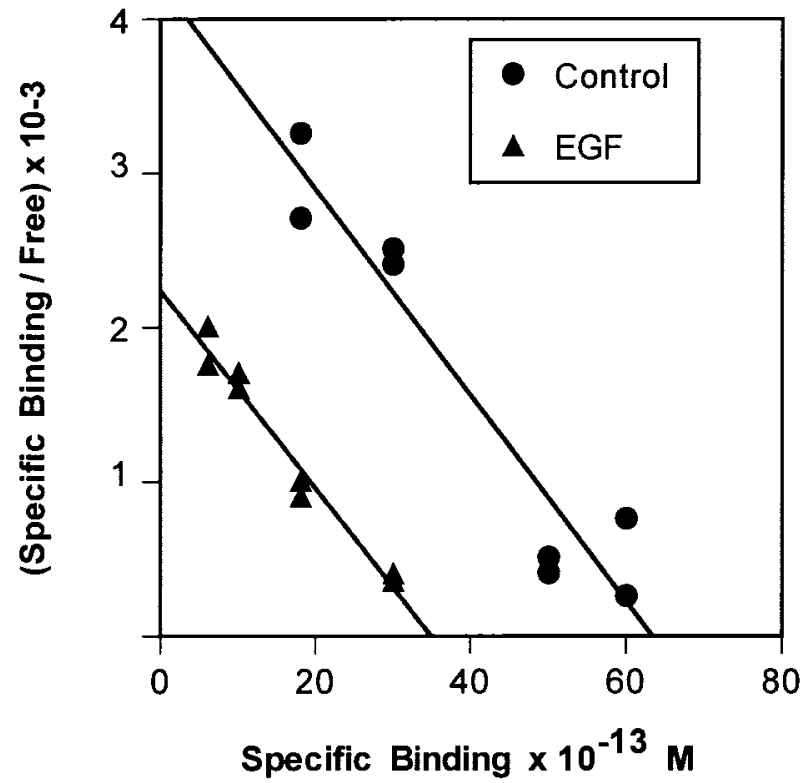

Figure 3 Effect of EGF on the binding of estradiol to ER- $\alpha$. MCF-7 cells were grown in six-well plates and treated with $0.4 \mathrm{ng} / \mathrm{ml}$ EGF for $24 \mathrm{~h}$. For the ligand binding assay, the cells were incubated with increasing concentrations of $\left[{ }^{3} \mathrm{H}\right]$ estradiol $\left(10^{-12}-10^{-7} \mathrm{M}\right)$ in the absence $\left(B_{\mathrm{T}}\right)$ or presence $\left(B_{\mathrm{N}}\right)$ of a 200 -fold molar excess of diethylstilbestrol. The results were graphically represented according to the Scatchard equation, $B_{\mathrm{S}}=B_{\mathrm{T}}-B_{\mathrm{N}^{\prime}}$ where $B_{\mathrm{T}}$ is total binding, $B_{\mathrm{N}}$ is nonspecific binding, $B_{\mathrm{S}}$ is specific binding. A representative assay of control and EGF-treated cells is shown. The experiment was repeated three times.

approximately $60 \%$ was observed at $9 \mathrm{~h}$. The amount of ER- $\alpha$ mRNA remained suppressed for $48 \mathrm{~h}$. These data suggest that the decrease in protein concentration can be attributed to a decrease in mRNA concentration.

\section{Effect of EGF on the ER-a gene transcription}

To determine if the decrease in mRNA was due to a transcriptional or post-transcriptional event, changes in the transcription of the ER- $\alpha$ gene were examined using an in vitro nuclear run-on transcription assay. Cells were treated with EGF for 1, 3, 6 and $24 \mathrm{~h}$ and nuclei were isolated. Newly synthesized RNA was isolated and hybridized to blots containing probes for ER- $\alpha$ and 36B4. The level of transcription was determined by autoradiography and quantified by scanning densitometry. Transcription of the 36B4 gene was used as an internal control and the relative change in ER- $\alpha$ transcription was normalized to the signal obtained for 36B4. The results are shown in Fig. 2. Following treatment with EGF, there was a decrease of $70 \%$ in ER- $\alpha$ gene transcription, suggesting that EGF regulates expression of ER- $\alpha$ through a transcriptional mechanism. 


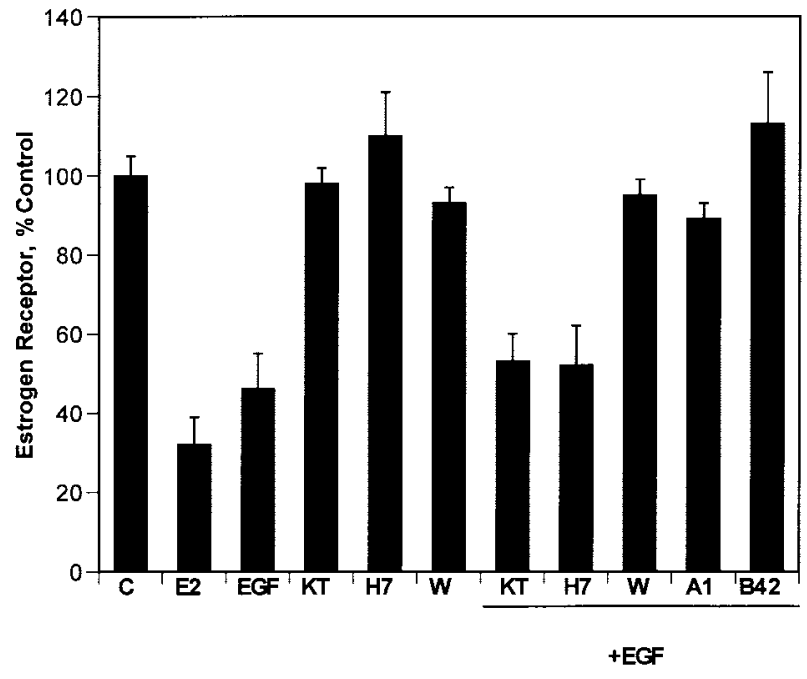

Figure 4 Effect of protein kinase inhibitors on the EGF regulation of ER- $\alpha$. MCF-7 cells were grown as described in Fig. 1 and treated with $1 \mathrm{nM}$ estradiol, $0 \cdot 4 \mathrm{ng} / \mathrm{ml} \mathrm{EGF,} 50 \mu \mathrm{M}$ KT5720, $100 \mathrm{nM}$ wortmannin, $50 \mu \mathrm{M} \mathrm{H7}, 50 \mu \mathrm{M}$ tyrphostin $\mathrm{A} 1$ or $50 \mu \mathrm{M}$ tyrphostin B42 for $6 \mathrm{~h}$. The concentration of ER- $\alpha$ was measured by enzyme immunoassay as described in Materials and Methods. The results are expressed as percentages of control values. Each point represents the mean value of five experiments \pm S.D. C, control; $E_{2}$, estradiol; KT, KT5720; W, wortmannin; A1, tyrphostin A1; B42, tyrphostin B42.

The EGF receptor pathway in the regulation of ER-a gene expression

To provide insight into the pathway activated by EGF in the regulation of ER- $\alpha$, several inhibitors of signal transduction were employed. To inhibit tyrosine kinase activity, tyrphostins, a group of low molecular weight compounds, were used (Reddy et al. 1992). Cells were treated with $50 \mu \mathrm{M}$ tyrphostins A1 or B42 for $6 \mathrm{~h}$ in the presence or absence of $0.4 \mathrm{ng} / \mathrm{ml} \mathrm{EGF}$. The concentration of ER- $\alpha$ protein was measured using the enzyme immunoassay. The effects of tyrphostins A1 and B42 on the regulation of ER- $\alpha$ protein concentration by EGF are shown in Fig. 4. The tyrphostins had no effect on the ER- $\alpha$ protein concentration. However, when added simultaneously with EGF to the cells, both inhibitors blocked the effects of EGF on ER- $\alpha$ protein concentration.

Since a plausible pathway for growth factor signaling is through second messenger enzyme cascades, inhibitors of the protein kinases A, B and C were also employed. To inhibit protein kinase A, KT5720 (Kase 1987) was used. The potent and selective synthetic protein kinase C inhibitor, $\mathrm{H}-7$, was employed to block protein kinase $\mathrm{C}$ (Hidaka 1984). To inhibit protein kinase B, wortmannin (KY 12420) was selected. It is a fungal metabolite that acts as a potent inhibitor of phosphatidylinositol 3-kinase (PI 3-kinase) (Vlahos et al. 1994) and therefore indirectly inhibits protein kinase B. MCF-7 cells were treated with

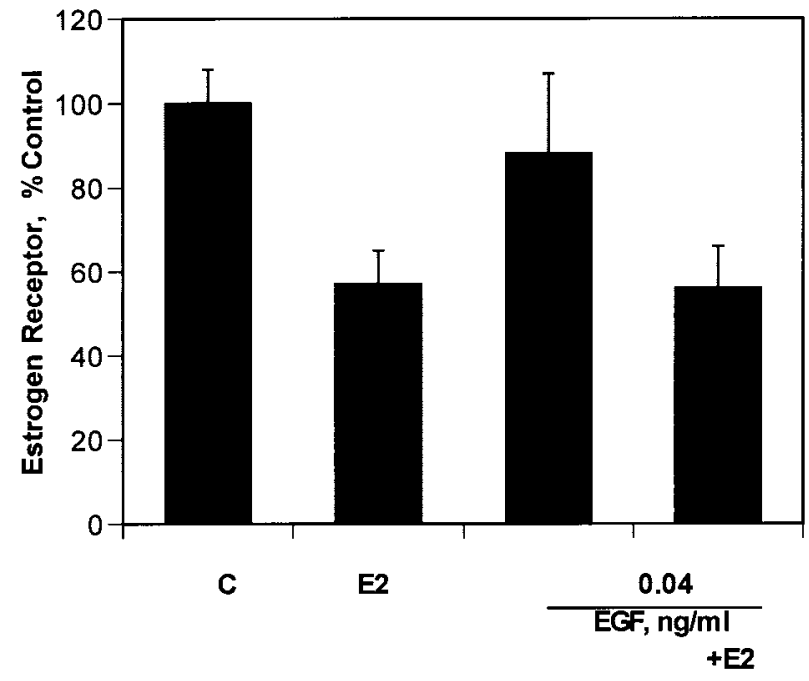

Figure 5 Effect of EGF on ER- $\alpha$ protein concentration in serumfree medium. MCF-7 cells were grown as described in Fig. 1. At the time of treatment, the medium was replaced with serum-free medium. The cells were treated with $1 \mathrm{nM}$ estradiol, $0 \cdot 4 \mathrm{ng} / \mathrm{ml}$ EGF or estradiol and EGF for $6 \mathrm{~h}$. The concentration of ER- $\alpha$ was determined by enzyme immunoassay as described in Materials and Methods. The results are presented as percentages of control values. Each point represents the mean value of four experiments \pm S.D.

$50 \mu \mathrm{M}$ KT5720, $50 \mu \mathrm{M}$ H7 or $100 \mathrm{nM}$ wortmannin in the presence or absence of $0.4 \mathrm{ng} / \mathrm{ml}$ EGF for $6 \mathrm{~h}$. Estrogen receptor protein concentration was determined using the enzyme immunoassay. The results are presented in Fig. 4. While none of the protein kinase inhibitors had an effect on the concentration of ER- $\alpha$, wortmannin blocked the EGF-mediated decrease in ER- $\alpha$ by approximately $90 \%$, suggesting that protein kinase B may mediate the effect of EGF on ER- $\alpha$ expression. Similar results were also obtained at the level of ER- $\alpha$ mRNA (data not shown).

\section{Dependence of the EGF effect on a serum factor}

To determine whether serum influenced the EGF response, MCF-7 cells were placed in serum free medium and treated with $1 \mathrm{nM}$ estradiol, $0.4 \mathrm{ng} / \mathrm{ml}$ EGF or estradiol and EGF simultaneously for $6 \mathrm{~h}$. The concentration of ER- $\alpha$ protein was determined using the enzyme immunoassay and the results are presented in Fig. 5. In the absence of serum, estradiol induced the expected decrease in ER- $\alpha$ protein concentration. In contrast to estradiol, treatment with EGF had no significant effect on the concentration of ER- $\alpha$ nor did it affect the estradiolinduced decrease in ER- $\alpha$, suggesting that the effect of the growth factor on ER- $\alpha$ requires serum. To test whether the EGF response was dependent on serum, the cells were treated with $0 \cdot 4 \mathrm{ng} / \mathrm{ml} \mathrm{EGF}$ and increasing concentrations of charcoal-stripped calf serum. Following a $6 \mathrm{~h}$ treatment, 


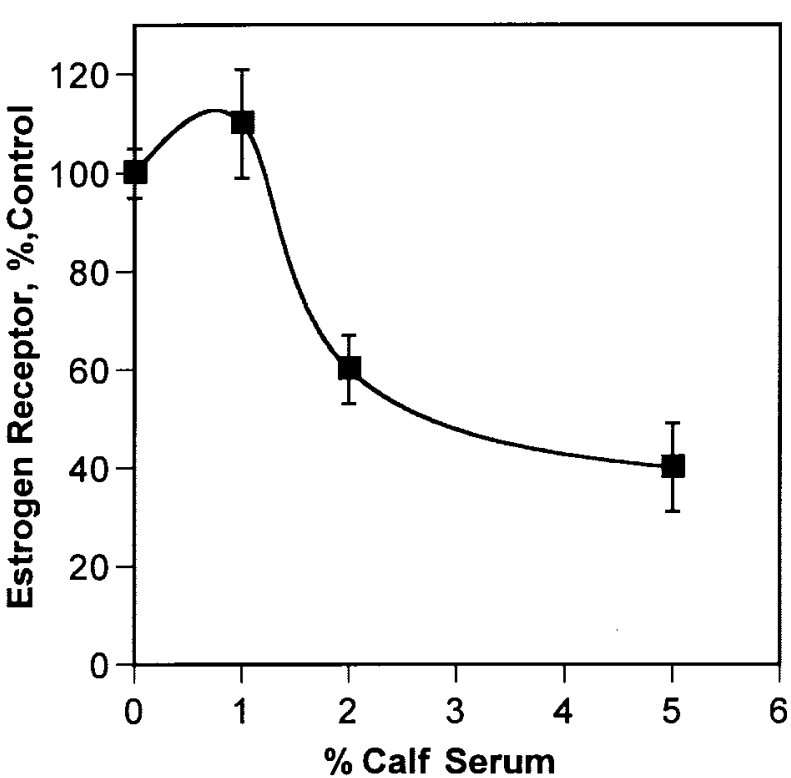

Figure 6 Effect of serum concentration on EGF regulation of ER- $\alpha$. MCF-7 cells were grown as described in Fig. 1. After 2 days, the medium was changed to phenol red-free IMEM supplemented with increasing concentrations of charcoal-stripped serum from 0 to $5 \%$. Cells were treated with $0 \cdot 4 \mathrm{ng} / \mathrm{ml} \mathrm{EGF}$ for $24 \mathrm{~h}$. The concentration of ER- $\alpha$ was determined by enzyme immunoassay as described in Materials and Methods. The results are presented as percentages of control values. Each point represents the mean value of three experiments \pm S.D.

the amount of ER- $\alpha$ was measured using the enzyme immunoassay. Figure 6 demonstrates an inverse relationship between the EGF response and the amount of serum. In the absence or presence of $1 \cdot 125 \%$ serum, EGF had no effect on ER- $\alpha$ expression, whereas, in the presence of $2.5 \%$ and $5 \%$ serum, there was a $40 \%$ and $60 \%$ decrease in ER- $\alpha$ respectively. These results suggest that a serum factor is necessary for the decrease in ER- $\alpha$ protein expression mediated by EGF.

\section{Effect of EGF on the activity of ER-a}

Treatment of MCF-7 cells with estradiol increases the progesterone receptor concentration in an ER-mediated manner. To determine whether EGF affected the activity of ER- $\alpha$, the ability of estradiol to induce progesterone receptor in the presence of high and low concentrations of EGF was measured. In this study, MCF-7 cells were treated with $1 \mathrm{nM}$ estradiol, 0.4 or $100 \mathrm{ng} / \mathrm{ml}$ EGF or estradiol and EGF for $6 \mathrm{~h}$ and progesterone receptor protein was measured using an enzyme immunoassay. The results presented in Fig. 7 demonstrate that EGF had a concentration-dependent effect on the expression of progesterone receptor. High concentrations of EGF induced a small but significant twofold increase in progesterone receptor which was blocked by the antiestrogen, ICI-

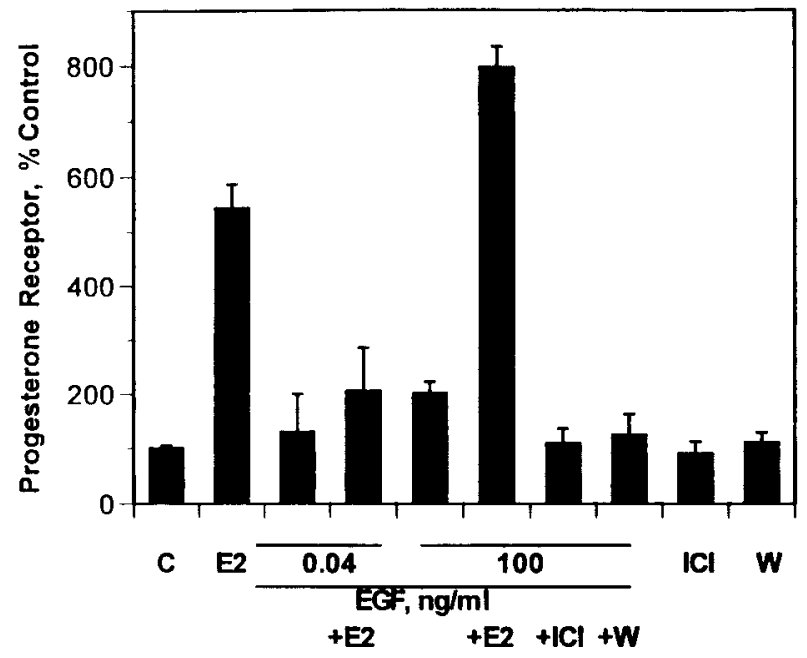

Figure 7 Effect of EGF on estradiol induction of progesterone receptor. MCF-7 cells were grown as described in Fig. 1 and treated with $1 \mathrm{nM}$ estradiol, $0 \cdot 4$ or $100 \mathrm{ng} / \mathrm{ml} \mathrm{EGF}$, or estradiol and EGF for $6 \mathrm{~h}$. The concentration of the progesterone receptor was measured by the enzyme immunoassay as described in Materials and Methods. The results are expressed as percentages of control values. Each point represents the mean value of eight experiments \pm S.D.

164,384, and by the PI 3-kinase inhibitor, wortmannin. Estradiol induced a fivefold increase in progesterone receptor protein concentration and, when estradiol and EGF were added simultaneously, there was an additive effect on progesterone receptor expression (sevenfold). These results are similar to previous studies (Ignar-Trowbridge et al. 1993, Kato et al. 1995, El-Tanani \& Green 1997a,b) which demonstrate hormone-independent activation of ER- $\alpha$. More interesting than the effect of high concentration was the effect of low concentrations of EGF on ER- $\alpha$ activity. In contrast to high concentrations, low concentrations of the growth factor did not induce progesterone receptor expression. When low concentrations of EGF were added simultaneously with estradiol, the growth factor blocked estradiol induction of progesterone receptor, suggesting that low concentrations of EGF inhibit ER- $\alpha$ activity. In the absence of serum, the ability of low concentrations of EGF to block estradiol induction of progesterone receptor was lost (data not shown), suggesting that a serum factor is also necessary for the effect of low concentrations of EGF on ER- $\alpha$ activity.

\section{Discussion}

The proliferation of breast cancer cells can be stimulated by estrogens and various growth factors such as EGF (Tsai \& O’Malley 1994, Katzenellenbogen 1996, Picard et al. 1997). Although steroid hormones and growth factors are thought to exert their effects through different receptors 
and signal transduction pathways, there is evidence for a cross-talk between these pathways (Ignar-Trowbridge et al. 1993, Das et al. 1994, Curtis et al. 1996). However, the mechanism of cross-talk is poorly understood and the results appear to be contradictory (Ignar-Trowbridge et al. 1996). Estrogens upregulate autocrine and paracrine polypeptide growth factors and, in turn, growth factors may utilize the ER to mediate their effects. Growth factors may also act to amplify the actions of estrogen.

In this study, we sought to understand the effects of EGF on the expression and activity of ER- $\alpha$. An earlier study had shown that treatment with EGF decreases the number of ER- $\alpha$ binding sites by approximately $50 \%$ without altering the affinity of the receptor (Cornier et al. 1989). In this study, we demonstrate a similar decrease in the number of ER- $\alpha$ binding sites with no effect on the affinity of the receptor. In addition, this study demonstrates that the decrease in estrogen binding sites is due to a decrease in ER- $\alpha$ protein, resulting from inhibition of transcription of the ER- $\alpha$ gene.

Members of the EGF receptor family are known to form homo- and heterodimeric receptor complexes which activate distinct signaling pathways by recruiting different effector proteins. To identify the signal pathway involved in mediating the effects of EGF on ER- $\alpha$ expression, several inhibitors of protein kinases were employed. In this study, the inhibitor $\mathrm{H} 7$ did not block regulation of ER- $\alpha$, suggesting that protein kinase $\mathrm{C}$ is not involved in mediating the effects of EGF on ER- $\alpha$ expression. In contrast to $\mathrm{H} 7$, tyrphostins $\mathrm{A} 1$ and B42 and wortmannin blocked the growth factor response, suggesting that the effects of EGF are mediated by the EGF receptor and phosphatidylinositol 3-kinase. This finding is in agreement with earlier reports (Ignar-Trowbridge et al. 1995, 1996). Activation of homodimers or heterodimers of EGF and either erbB3 or erbB4 is believed to activate phosphatidylinositol 3-kinase and the downstream target of phosphatidylinositol 3-kinase, protein kinase B (Akt), which is overexpressed in MCF-7 cells (Jones et al. 1995). In Rat-1 cells, EGF-induced activation of protein kinase B is mediated by phosphatidylinositol 3-kinase (Burgering \& Coffer 1995). In our study, wortmannin blocked the EGF-mediated decrease in ER- $\alpha$, suggesting that phosphatidylinositol 3-kinase, and indirectly protein kinase B, may mediate the EGF response. Interestingly, the effects of EGF on regulation of the ER- $\alpha$ gene were observed only in medium supplemented with serum. However, the role of additional serum factors in the mediating EGF response is not known and is currently under investigation.

To understand the cross-talk between EGF and ER- $\alpha$, most studies have investigated the effects of high concentrations of EGF $(10-100 \mathrm{ng} / \mathrm{ml})$ and demonstrate an activation of the ER (Ignar-Trowbridge et al. 1993, Kato et al. 1995, El-Tanani \& Green 1997a,b). High doses of EGF increase ER- $\alpha$ activity in the uterus of immature rats and mice, in ovariectomized adult rats (Sumida \&
Pasqualim 1989, Ignar-Trowbridge et al. 1992, Hana \& Murphy 1994) and in vitro (Tsai \& O’Malley 1994, Katzenellenbogen 1996, Picard et al. 1997). Similar to previous studies, high concentrations of EGF activated ER- $\alpha$. In striking contrast to high doses, low concentrations of EGF inhibited ER- $\alpha$ activity. The difference between the effects of high and low concentrations of the growth factor may be due to the activation of different members of the EGF receptor family by different concentrations of EGF. Low concentrations of EGF are thought to act through the EGF receptor, whereas, high concentrations of EGF have been shown to induce phosphorylation of erbB2 and erbB3. Activation of alternate signal pathways may explain, in part, the different effects of EGF on ER- $\alpha$ activity. It is interesting to note that gp30, a ligand for the EGF receptor family which acts in part through erbB2, also blocks ER- $\alpha$ activity (Saceda et al. 1996), providing additional evidence that ER- $\alpha$ activity is differentially regulated through alternate signal transduction pathways.

The data from this study provide evidence that the cross-talk between the EGF receptor family and ER- $\alpha$ is complex. While high concentrations of EGF activate the ER, low concentrations of EGF have the opposite effect of blocking the activity of the receptor. The effect of the growth factor on the activity is uncoupled from its effect on expression since both concentrations inhibited transcription of the ER- $\alpha$ gene. The effects of EGF on ER- $\alpha$ gene transcription appear to be mediated by the EGF receptor and phosphatidylinositol 3-kinase but require an additional serum factor. Although the precise mechanisms of regulation have yet to be defined, it is clear that ER- $\alpha$ provides a site for integration of multiple signal transduction pathways.

\section{Acknowledgements}

We thank Dr M E Lippman for helpful discussions. This work was supported by the National Institutes of Health grants CA51908 and CA59493.

\section{References}

Adachi K, Kurachi H, Homma H, Adachi H, Imai T, Sakata M, Higashiguchi O, Yamaguchi M, Morishige KI, Sakoyama Y \& Miyake A 1995 Estrogen induces epidermal growth factor (EGF) receptor and its ligands in human fallopian tube: involvement of EGF but not transforming growth factor-alpha in estrogen-induced tubal cell growth in vitro. Endocrinology 136 2110-2119.

Bunone G, Briand PA, Miksicek RJ \& Picard D 1996 Activation of the unliganded estrogen receptor by EGF involves the MAPK pathway and direct phosphorylation. EMBO Journal 15 2174-2183.

Burgering BMT \& Coffer PJ 1995 Protein kinase B (c-Akt) in phosphatidyl inositol-3-OH kinase signal transduction. Nature 376 599-602. 
Cho H, Lei ZM \& Rao CV 1994 Transcriptional and posttranscriptional mechanisms in EGF regulation of human chorionic gonadotropin subunits and hCGR gene expression in human choriocarcinoma cells. Endocrinology 135 962-970.

Cornier EM, Wolf MF \& Jordan VC 1989 Decrease in estradiolstimulated progesterone receptor production in MCF-7 cells by EGF and possible clinical implications for paracrine-regulated breast cancer growth. Cancer Research 49 576-580.

Curtis SW, Washhorn T, Sewall C, DiAugustine R, Lindzey Y, Couse JF \& Korach KS 1996 Physiological coupling of growth factors and steroid receptor signaling pathways: ERKO mice lack estrogen-like response to EGF. Proceedings of the National Academy of Sciences of the USA 93 12626-12630.

Das SK, Tsukamura H, Paria BC, Andrews GK \& Dey SK 1994 Different expression of EGF receptor gene and regulation of EGFR bioactivity by progesterone and estrogen in the adult mouse uterus. Endocrinology 134 971-981.

Earp HS, Dawson TL, Li X \& Yu H 1995 Hetrodimerization and functional interaction between EGF receptor family members: a new signaling paradigm with implications for breast cancer research. Breast Cancer Research and Treatment 35 115-132.

El-Tanani MKK \& Green CD 1997a Interaction between estradiol and growth factors in the regulation of specific gene expression in MCF-7 human breast cancer cells. Journal Steroid Biochemistry 60 269-276.

El-Tanani MKK \& Green CD $1997 b$ Two separate mechanisms for ligand-independent activation of the estrogen receptor. Molecular Endocrinology 11 928-937.

Hafner F, Holler E \& von Angerer E 1996 Effects of growth factors on estrogen receptor mediated gene expression. Journal Steroid Biochemistry 58 385-393.

Hana V \& Murphy CJ 1994 Interdependence of EGF and IGF-I expression in the mouse uterus. Endocrinology 135 107-112.

Hidiaka H, Inagaki M, Kawamoto S \& Sasaki Y 1984 Isoquinolinesulfonamides, novel and potent inhibitors of cyclic nucleotide dependent protein kinase and protein kinase C. Biochemistry 23 5036-5041.

Ignar-Trowbridge DM, Nelson KG, Bidwell MC, Curtis SW, Washburn TF, McLachlan JA \& Korach KS 1992 Coupling of dual signaling pathways: EGF action involves the ER. Proceedings of the National Academy of Sciences of the USA 89 4658-4662.

Ignar-Trowbridge DM, Teng CT, Ross KA, Parker MG, Korach KS \& McLachlan JA 1993 Peptide growth factors elicit estrogen receptor-dependent transcriptional activation of an estrogenresponsive element. Molecular Endocrinology 7 992-998.

Ignar-Trowbridge DM, Pimentel M, Teng CT, Korach KS \& McLachlan JA 1995 Cross talk between peptide growth factors and estrogen receptor signaling systems. Environmental Health Perspectives 103 35-38.

Ignar-Trowbridge DM, Pimentel MG, Parker MG, McLachlan JA \& Korach KS 1996 Peptide growth factors cross-talk with the estrogen receptor requires the $\mathrm{A} / \mathrm{B}$ domain and occurs independent of protein kinase C or estradiol. Endocrinology 137 1735-1744.

Ingles SA, Ross RK, Yu MC, Irvine RA, La Pera G, Haile RW \& Coetzee GA 1997 Association of prostate cancer risk with genetic polymorphisms in vitamin $\mathrm{D}$ receptor and androgen receptor. Journal of the National Cancer Institute 89 166-170.

Jensen EV 1996 Steroid hormones, receptors, and antagonists. Annals of the New York Academy of Science 784 1-16.

Jones PF, Jakubowitz T, Pitossi FJ, Maurer F \& Hemmings BA 1995 Molecular cloning and identification of a serine/threonine protein kinase of the second-messenger subfamily. Nature 376 599-602.

Kase H, Iwahashi K, Nakanishi S, Matsuda Y, Yamada K, Takahashi M, Murakata C, Stao A \& Kaneko M 1987 K-252 compounds, novel and potent inhibitors of protein kinase $\mathrm{C}$ and cyclic nucleotide-dependent kinases. Biochemical and Biophysical Research Communications 142 436-440.
Kastner P, Bocquel M, Turcotte B, Garnier JM, Horwitz KB, Chambon P \& Gronemeyer H 1990 Transient expression of human and chicken progesterone receptors does not support alternative translational initiation from a single mRNA as the mechanism generating two receptor isoforms. Journal of Biological Chemistry 265 $12163-12167$.

Kato S, Endoh H, Masuhiro Y, Kitamoto T, Uchiyama S, Nishida E, Kawashima H, Metzger D \& Chambon P 1995 Activation of the estrogen receptor through phosphorylation by MAPK. Science $\mathbf{2 7 0}$ 1491-1494.

Katzenellenbogen BS 1996 Estrogen Receptors: Bioactivity and Interactions with Cell Signaling Pathways. Biology of Reproduction 54 287-293.

Katzenellenbogen BS, Montano MM, Ekena K, Herman ME \& McInery EM 1997 Antiestrogens: mechanisms of action and resistance in breast cancer. Breast Cancer Research and Treatment 44 23-38.

Mangelsdorf DJ, Thummel C, Beato M, Herrlich P, Schutz G, Umesano K, Blumberg B, Kastner P, Mark M, Chambon P \& Evans RM 1995 The nuclear receptor superfamily: the second decade. Cell 83 835-839.

Masiakowski P, Breathnach R, Bloch J, Gannon F, Krust A \& Chambon P 1982 Cloning of cDNA sequences of hormoneregulated genes from MCF-7 human breast cancer cell line. Nucleic Acids Research 10 7895-7903.

Norderu SK, Moyer ML \& Bona BJ 1994 The coupling of multiple signal transduction pathways with steroid response mechanisms. Endocrinology 34 1723-1732.

O'Malley BW, Schrader T, Mani S, Smith C, Weigel N, Conneely OZM \& Clark JH 1994 An alternate ligand-independent pathway for activation of steroid receptors. Recent Progress in Hormone Research 50 333-347.

Picard P, Bunone G, Liu JW \& Donze O 1997 Steroid-independent activation of steroid receptors in mammalian and yeast cells in breast cancer. Biochemical Society Transactions 25 597-602.

Reddy KB, Mangold GL, Tandon AK, Yoneda T, Mundy GR, Zilberstein A \& Osborne CK 1992 Inhibition of breast cancer cells growth in vitro by a tyrosine kinase inhibitor. Cancer Research $\mathbf{5 2}$ 3636-3641.

Saceda M, Lippman ME, Chambon P, Lindsey RK, Ponglikitmongkol M, Puente M \& Martin MB 1988 Regulation of the estrogen receptor in MCF-7 cells by estradiol. Molecular Endocrinology 2 $1157-1162$

Saceda M, Grunt TW, Colomer R, Lippman ME, Lupu R \& Martin MB 1996 Regulation of estrogen receptor concentration and activity by an erbB/HER ligand in breast carcinoma cell lines. Endocrinology 137 4322-4330.

Stancel GM, Gardner RM, Kirland JL, Liu TH, Lingham RB, Loose-Mitchell DS, Mukku VR, Orengo CA \& Verner G 1987 Interactions between estrogen and EGF in uterine growth. Advances in Experimental Medical Biology 230 99-118.

Stoica A, Saceda M, Fakhro A, Solomon HB, Fenster BD \& Martin MB 1997 The role of transforming growth factor-B in regulation of estrogen receptor expression in the MCF-7 breast cancer cell line. Endocrinology 138 1498-1505.

Sumida C \& Pasqualim JR 1989 Antiestrogens antagonize the stimulatory effect of EGF on the induction of progesterone receptor in fetal uterine cells in culture. Endocrinology 124 1242-1259.

Tsai MJ \& O'Malley BW 1994 Molecular mechanisms of action of steroid/thyroid receptor superfamily members. Annual Review of Biochemistry 63 451-486.

Vlahos CJ, Matter WF, Kui KY \& Brown RF 1994 A specific inhibitor of phosphatidylinositol 3-kinase, 2-(4-morpholinyl)-8phenyl-4H-1-benzopyran-4-one (LY294002). Journal of Biological Chemistry 269 5241-5248.

Received 5 July 1999

Accepted 2 December 1999 